\title{
Rancang Bangun dan Performa Generator DC Low Head Picohydro Di Daerah Cipanas-Bogor
}

\author{
Achmad Maulana Soehada ${ }^{1, *}$ dan Tanu Giriduady Putra Negara ${ }^{2}$

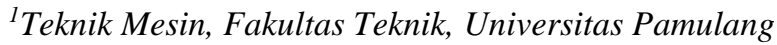 \\ Jl. Surya Kencana No. 1 Pamulang, Tangerang Selatan, Banten 15417, Indonesia \\ ${ }^{2}$ Physics - Energy Engineering Faculty of Clean Energy \& Climate Change, Universitas Surya \\ Grand Serpong Mall Lt. 1 Unit F8 \& F9 Jl. M.H. Thamrin Km 2.7, Tangerang, Banten, Indonesia \\ E-mail: dosen01547@unpam.ac.id \\ Masuk:8 September 2018 Direvisi :29 November $2018 \quad$ Disetujui :8 Januari 2019

\begin{abstract}
Abstrak: Desain pembangkit listrik tenaga air low head picohydro dirancang sebagai pembangkit listrik skala kecil. Pada penelitian ini, desain pembangkit listrik ini memiliki ketinggian permukaan air (head) $3 \mathrm{~m}$ dan mampu menghasilkan listrik kurang dari 100 - $5000 \mathrm{~W}$. Rancang bangun low head picohydro dikonstruksi di Cipanas-Bogor dengan debit air maksimal 13 l/s. Low head picohydro menggunakan modifikasi turbin kaplan sebagai penggerak generator DC. Hasil rancang bangun sistem pembangkit low head picohydro dapat digunakan sebagai acuan untuk skala yang lebih besar. Performa dari low head picohydro yang telah dibuat mampu menghasilkan output tegangan 72 volt (tanpa beban) dan 40 volt DC (dengan beban). Generator DC low head picohydro menghasilkan arus listrik maksimum 3,6 amper, daya keluran 144 watt dan efisiensi $69 \%$.
\end{abstract}

Kata kunci : Debit, Genertor DC, Low Head Picohydro, Turbin Kaplan

\begin{abstract}
The low head picohydro hydro power plant is design as a small scale power plant. The power plant has a water level of $3 \mathrm{~m}$ and capable to produce electricity less than $100-5000 \mathrm{~W}$. The low head picohydro design was constructed in Cipanas-Bogor with a maximum water discharge of $13 \mathrm{l} / \mathrm{s}$. The low head picohydro uses Kaplan turbine modification as a DC generator drive. The results of the design of the picohydro low head generator system can be used as a reference for a larger scale. The performance of the picohydro low head that has been made is capable of producing an output voltage of 72 volts (no load) and 40 volts DC (with a load). Generator DC low head picohydro menghasilkan arus listrik maksimum 3,6 amper, daya keluran 144 watt dan efisiensi $69 \%$.
\end{abstract}

Keywords: Debit, DC Generator, Low Head Picohydro, Turbine Kaplan

\section{PENDAHULUAN}

Energi merupakan salah satu kebutuhan utama dalam kehidupan manusia. Peningkatan kebutuhan energi dapat menjadi indikator peningkatan kemakmuran, namun bersamaan dengan itu juga menimbulkan masalah dalam usaha penyediaannya. Oleh karena itu untuk menjamin ketersediaan energi di daerah pedalaman dan pulau terluar diperlukan pembangkit listrik yang mandiri untuk menunjang kehidupan manusia. Selokan atau parit merupakan sumber energi yang murah dan relatif mudah didapat, jika debit airnya konstan. Pembangkit listrik tenaga air adalah energi yang diperoleh dari air yang mengalir yang dimanfaatkan dalam wujud energi mekanis. Pemanfaatan energi air banyak dilakukan dengan menggunakan kincir atau turbin air. Low head picohydro adalah salah satu solusi energi alternatif yang ramah lingkungan karena sumber utama energi yaitu air dapat diperbaharui, biaya oprasional relatif murah dan sangat cocok ditempatkan di daerah terpencil. Pengembangan low head picohydro adalah upaya konstrukstif untuk mengajak masyarakat peduli lingkungan. Pembatasan ruang lingkup penelitian adalah sebagai berikut: rancang bangun low head picohydo menggunakan komponen-komponen tersedia dipasaran, peforma low head picohydo yang optimal dengan debit air dan bendungan serta pipa penstock. Dalam racangan ini dibuat perbedaan ketinggian air dari bendungan ke turbin $3 \mathrm{~m}$, beban kerja merupakan lampu 
pijar 12 volt DC dengan spesifikasi 5, 18, 25 dan 35 watt. Debit aliran dibuat $25 \%$ eqivalan dengan 2.4 1/s, $50 \%=5,5 \mathrm{l} / \mathrm{s}, 75 \%=8,0 \mathrm{l} / \mathrm{s}$ dan $100 \%=13 \mathrm{l} / \mathrm{s}$. Pokok bahasan dalam tulisan ini adalah output tegangan generator DC pada saat tanpa dan dengan beban. Output tegangan $(\mathrm{V})$, arus listrik (mA) pada saat diberi beban masing masing lampu pijar 5, 18, 25 dan 35 watt, daya (W) dan efisiensi generator DC.

\section{TINJAUAN PUSTAKA}

Pembangkit listrik tenaga air merupakan salah satu sumber energi listrik dengan mengandalkan aliran air dan perbedaan ketinggian permukaan air. Untuk pembangkit listrik skala kecil biasanya air tidak dibendung melainkan air dialirkan melalui pipa, kemudian air dialirkan ke arah turbin agar turbin berputar dan turbin memutar generator. Berdasarkan kapasitas yang dihasilkan pembangkit listrik tenaga air picohydro berkisar kurang dari $100 \mathrm{~W}$ sampai $5 \mathrm{KW}$. Ketinggian air pembangkit listrik tenaga air dibagi menjadi beberapa macam, diantarnya Low head hydropower dengan ketinggian air antara 1,5 - $30 \mathrm{~m}$.

Turbin adalah komponen utama dalam sistem pembangkit listrik tenaga air yang mengubah energi air menjadi energi gerak berupa putaran. Putaran yang dihasilkan akan di arahkan ke generator melalui shaft [1]. Shaft kemudian memutar generator sehingga generator dapat menghasilkan listrik. Umumnya turbin impuls digunakan dengan perbedaan effective head yang tinggi dan turbin reaksi digunakaan dengan perbedaan effective head yang rendah. Turbin Kaplan baik digunakan untuk semua jenis debit dan effective head, efisisnsinya tertinggi dari semua jenis turbin yang ada dan baik dalam segala kondisi aliran air. Turbin Kaplan terbuat dari baling-baling seperti pada kapal. Setiap baling-baling biasanya terdiri dari 3 bilah sampai dengan 6 bilah. Turbin Kaplan bekerja dengan prinsip reaksi atau mendapatkan gaya putar dari luar. Sebelum air memutar turbin air melewati guide fan yang berguna untuk memusatkan tenaga air agar air memiliki daya rotasi pada saat memasuki tubin.

Daya listrik yang dihasilkan dari low head picohydro tergantung dari besarnya debit air dan perbedaan ketinggian dari pintu masuk air dan pembuangan inlet yang dapat dipacai. Namun hal tersebut tidaklah semudah itu karena pada saat air menuju turbin ada rugi mayor dan rugi minor. Rugi mayor adalah adalah besar nilai kehilangan energi yang diakibatkan oleh gesekan antara fluida dengan dinding pipa lurus yang mempunyai luas penampang yang tetap. Rugi minor adalah besar nilai kehilangan energi aliran fluida di dalam pipa yang disebabkan oleh perubahan luas penampang jalan aliran, entrance, fitting, dan lain sebagainya (Akbar, 2012). Kehilangan energi yang dikonversikan ke dalam kehilangan ketinggian pada saluran tertutup memenuhi persamaan berikut [1] (Ferreres \& Font, Instalation of A New Hydropower Plant In Ockelbo (Sweden), 2010):

$$
h_{t}=k_{t} *\left(\frac{S}{b}\right)^{\frac{4}{3}} * \frac{v^{2}}{2 * g} * \sin \alpha
$$

Dimana $h_{t}$ : hilangnya head karena trashrack, $k_{t}$ : koefisien trashrack $(1,8), s$ : lebar profil dari arah aliran $(0,001 \mathrm{~m}), b$ : Jarak antar profil saringan $(0,01 \mathrm{~m}), v^{2}$ : kecepatan aliran $(0,793 \mathrm{~m} / \mathrm{s}), g$ : percepatan gravitasi bumi $\left(9,8 \mathrm{~m} / \mathrm{s}^{2}\right)$ dan $\alpha$ : sudut kemiringan saringan. Sementara itu kehilangan energi yang dikonversikan karena inlet penstock dapat didefinisikan melalui persamaan berikut

$$
h_{e}=k_{e} * \frac{\Delta v^{2}}{2 * g} h_{e}
$$

dimana $h_{e}$ : hilangnya head karena inlet penstock, $k_{e}$ : koefisien inlet penstock $(0,05), \Delta v^{2}:$ selisih kecepatan sebelum dan sesudah melewati inlet penstock $(0,793 \mathrm{~m} / \mathrm{s})$.

Penentuan koefisien gesek (f) dapat menggunakan diagram Moody, pipa yang digunakan untuk penstock adalah pipa 3 inci sepanjang 15,7 meter. Sebelum menentukan nilai (f) terlebih dahulu harus mencari nilai Reynold $(\mathrm{Re})$ dengan rumus (V. D)/ $\mu$ dan koefisien kekasaran pipa $(\varepsilon)$. Dalam penstock dengan bahan PVC maka dapat dicari nilai kekasaran pipa adalah. Nilai (Re) didefinisikan sebagai (Mantiq, 2017):

$$
R e=\frac{\rho * V * L}{\mu}
$$

Dengan melihat referensi maka dapat diketahui nilai dari kekasaran pipa ( $\varepsilon$ ) adalah 0.0015. Rumus dari relative roughness $=\frac{D}{\varepsilon}=\frac{0,08}{0,0015}=53.3$ untuk diameter pipa 3 inci. Sementara untuk kehilangan energi akibat gaya gesek fluida dapat didefinisikan sebagai berikut 


$$
h_{f}=f * \frac{L}{D} * \frac{v^{2}}{2 * g}
$$

dimana $h_{f}$ : hilangnya head karena gaya gesek fluida terhadap dinding pipa, $f$ : koefisien gesekan dinding pipa (nilai f didapat dari diagram Moody), L: panjang penstock $(15,7 \mathrm{~m}), D$ : diameter penstock $(0,08 \mathrm{~m}), \rho$ : masa jenis air $\left(1000 \mathrm{~kg} / \mathrm{m}^{3}\right), \mu$ : viskositas kinematik fluida pada 25 derajat celcius $\left(8,91 * 10^{-4}\right)$ dan $v^{2}$ : kecepatan aliran $(1,5 \mathrm{~m} / \mathrm{s})$. Untuk kehilangan energi akibat belokan pestock dapat didefinisikan melalui persamaan berikut

$$
h_{b}=K b * \frac{v^{2}}{2 * g}
$$

$h_{b}$ : hilangnya head karena belokan penstock dan $\mathrm{Kb}$ : koefisien sudut belokan $\alpha(0,2)$. Untuk kehilangan energi akibat pengecilan penstock dapat didefinisikan sebagai berikut

$$
h_{c}=k_{c} * \frac{v_{f}^{2}}{2 * g} h_{c}
$$

dimana $h_{c}$ : hilangnya head karena pengecilan penstock, $k_{c}$ : koefisien pengecilan penstock dan $v_{f}^{2}$ : Kecepatan aliran setelah air keluar dari pengecilan penstock $(1,5 \mathrm{~m} / \mathrm{s})$. Dapat diketahui total dari rugi-rugi mayor dan minor yang dikonversikan terhadap pengurangan ketinggian, merupakan total daya yang dikeluarkan:

$$
H_{n}=H-\left(h_{t}+h_{e}+h_{f}+h_{b}+h_{c}\right)
$$

Daya bersih berguna untuk mengetahui energi bersih yang dihasilkan oleh air yang menuju turbin memenuhi persamaan berikut:

$$
P_{n e t}=Q * H_{n} * \rho * g P_{n e t}
$$
$\left.\mathrm{m} / \mathrm{s}^{2}\right)$.

Dimana $Q$ : debit air , $H_{n}$ : net head $(1,62 \mathrm{~m}), \rho$ : densitas air $\left(1000 \mathrm{~kg} / \mathrm{m}^{3}\right)$, dan $g$ : percepatan gravitasi $(9,8$

\section{METODOLOGI}

Untuk memasang low head picohydro dibuat bendungan, ditentukan baling-baling turbin baru dilakukan pengukuran - pengukuran. Ketinggian air dari bendungan ke turbin adalah $\mathrm{H}=3$ meter, ketinggian tersebut dibilang dengan ketinggian kasar karena belum dikurangi dengan rugi-rugi mayor dan minor. Diagram alir penelitian seperti terlihat pada Gambar 1.
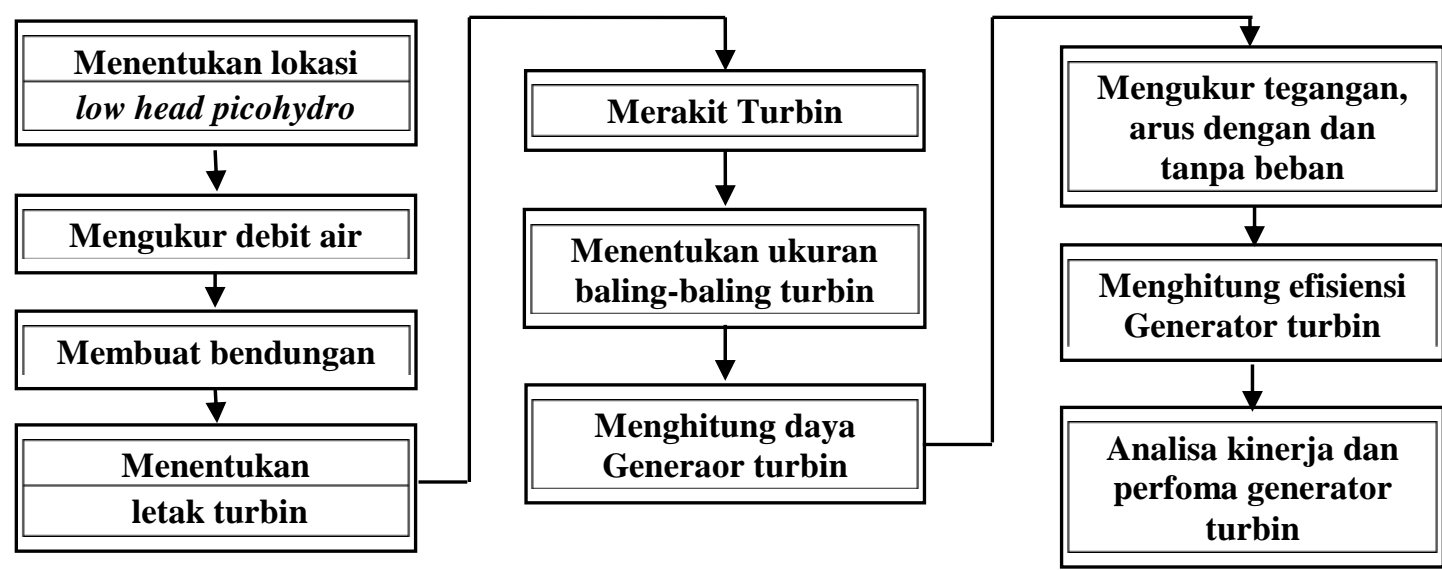

Gambar 1. Diagram alir penelitian 
Pengambilan data tegangan tanpa dan dengan beban dilakukan seperti Gambar 2, dimana beban merupakan lampu pijar bekerja pada 12 volt DC dengan spesifikasi 5, 18, 25 dan 35 watt. Generator DC yang digunakan 12 voit DC pada rentang 40 - $60 \mathrm{rpm}$ dan arus $1500 \mathrm{~mA}$.

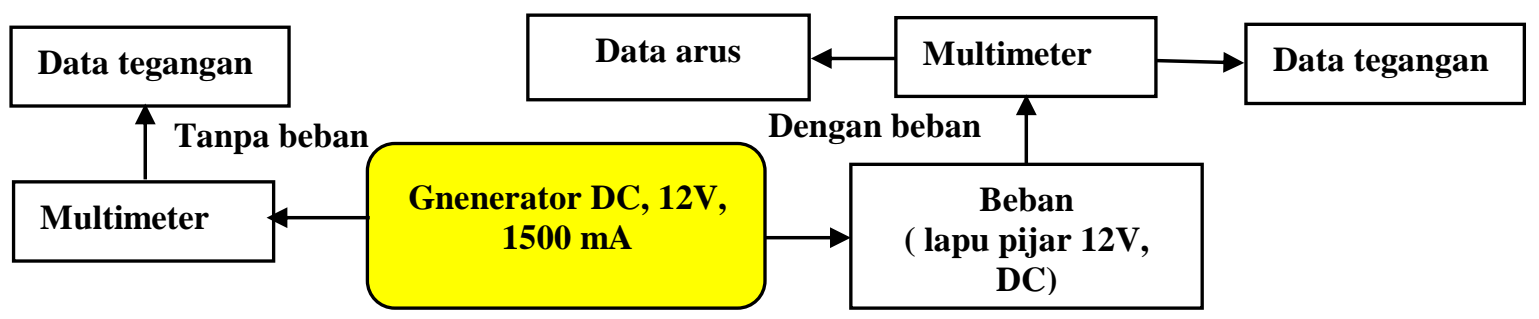

Gambar 2. Skema pengukuran Generator turbin dengan dan tanpa beban

Debit aliran $25 \%$ eqivalan dengan $2.4 \mathrm{l} / \mathrm{s}, 50 \%=5,5 \mathrm{l} / \mathrm{s}, 75 \%=8,0 \mathrm{l} / \mathrm{s}$ dan $100 \%=13 \mathrm{l} / \mathrm{s}$, seperti terlihat pada Gambar 3. Perencanaan tinggi permukaan air ke turbin adalah 3 meter, ketinggian tersebut dibilang dengan ketinggian kasar karena belum dikurangi dengan rugi-rugi mayor dan minor, seperti pada Gambar 4. Kerugian mayor dan minor dapat diketahui dengan memasukan data yang berkaitan dengan data mekanik seperti pada kajian pustaka di atas.

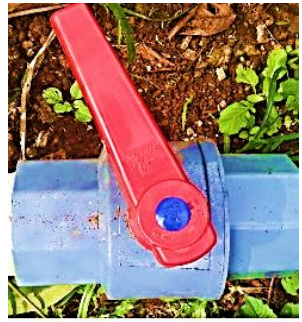

a)

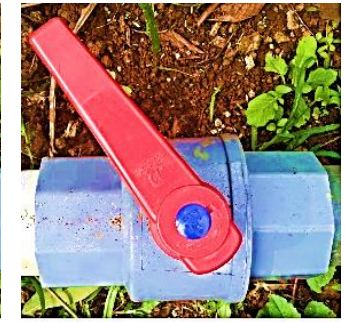

b)

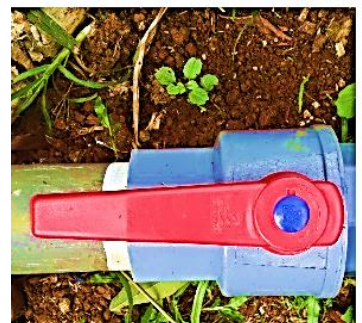

c)

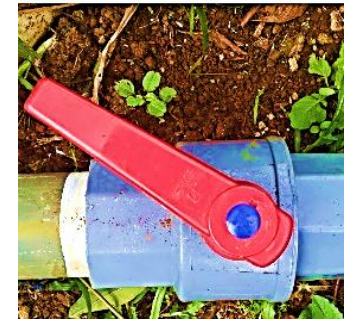

d)

Gambar 3. Bukaan kran a). $25 \%=2.4$ 1/s, b). $50 \%=5,51 / \mathrm{s}, \mathrm{c}) .75 \%=8,0$ 1/s dan d). $100 \%=13$ 1/s.

Turbin Kaplan adalah reaksi aliran ke dalam yang berarti fluida perubahan tekanan bekerja ketika bergerak melalui turbin. Turbin Kaplan terdiri dari 3-6 baling-baling dan bekerja dengan prinsip reaksi atau mendapatkan gaya putar dari luar. Pada turbin air melewati guide fan akan memiliki daya rotasi dan kecepatannya dapat diatur tergantung pada debit air.Guide fan akan terbuka $45^{\circ}$ derajat terhadap poros turbin untuk memaksimalkan efisiensi dari turbin, seperti pada Gambar 4a. Generator DC yang digunakan pada penetian ini dengan spesifiksi: kapasitas normal 20W, $12 \mathrm{~V}$ dan 1,5 A, seperti pada Gambar 4b. Generator DC ini dapat beroperasi dalam kecepatan putar rendah (dibawah $180 \mathrm{rpm}$ ) dan dilengkapi dengan gear box untuk mempercepat putaran turbin Kaplan.

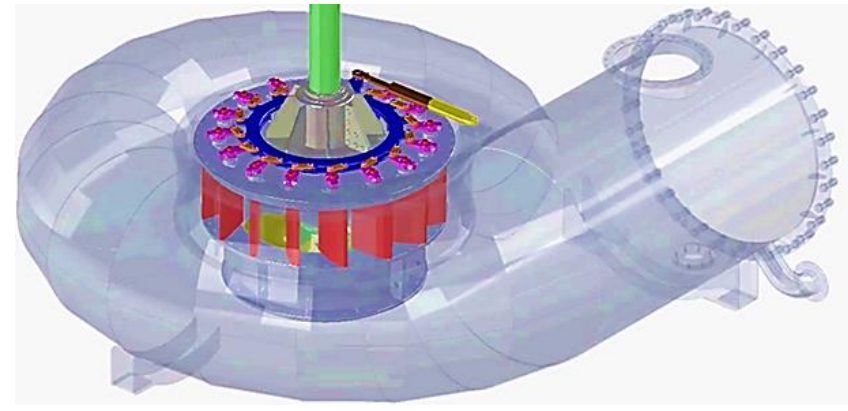

a)

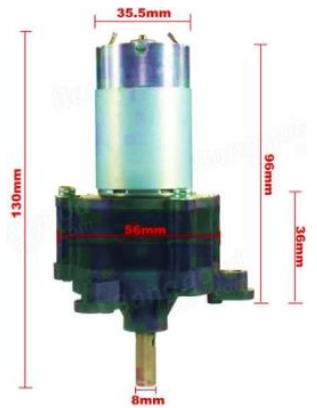

b)

Gambar 4. a) Baling-baling pada sitem turbin Kaplan dan b) Generator DC

Design bendungan untuk reaction turbin yaitu turbin mekanika yang digerakan oleh energi potennsial yang berasal dari aliran air yang mengubah energi potensial menjadi energi rotasi yang akan memutar generator. Perbedaan ketinggian air dari bendungan ke turbin adalah 3 meter, ketinggian tersebut masih belum dikurangi dengan rugi-rugi mayor dan minor, seperti pada Gambar 6a. Perakitan dilapangan ditunjukkan seperti pada 
Gambar 6b. Kerugian mayor dan minor dapat diketahui dengan menggunakan persamaan persamaan dalam teori di atas.

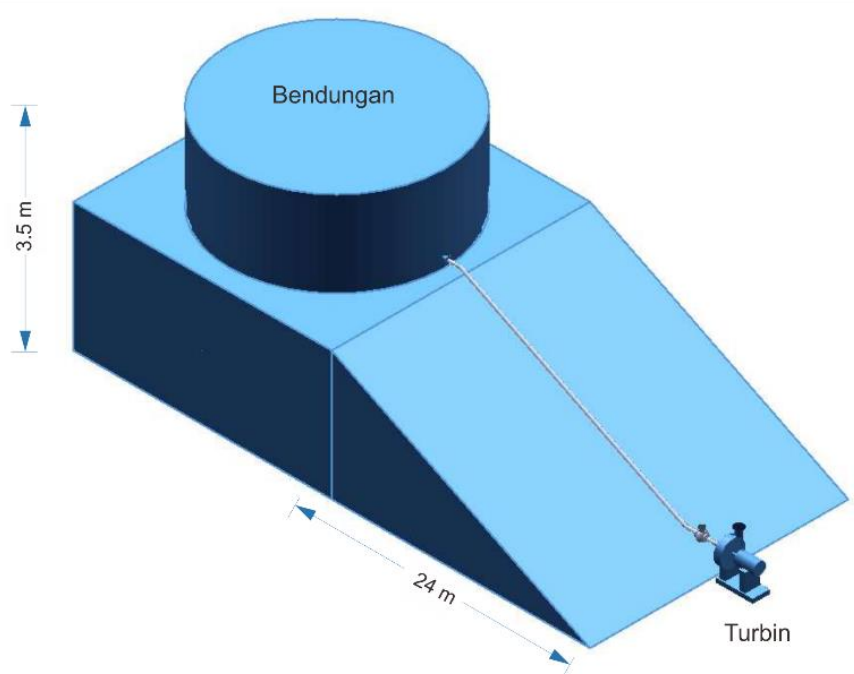

a)

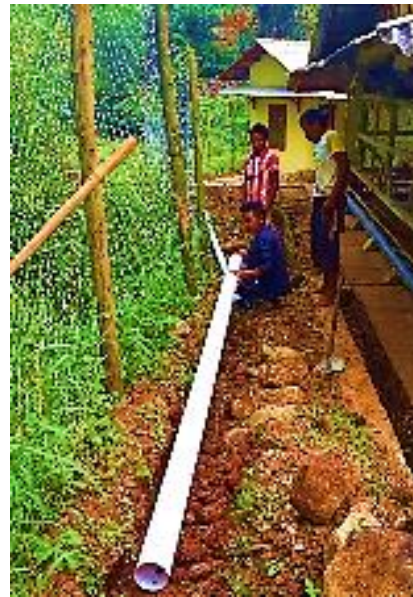

b)

Gambar 4. a) Perencanaan bendungan pada generator turbin: low head picohydro dan b) sistem perpipaan yang terpasang

\section{HASIL DAN PEMBAHASAN}

Hubungan bukaan stop kran $(\%)$ terhadap debit air (1/s) memenuhi korelasi sebagai berikut: $\mathrm{y}=0,081 \mathrm{x}+$ 0,053, artinya dengan tingkat kesalahan 5,3\% seperti pada Gambar 5. Debit air (1/s) relatif bertambah besar sebanding dengan bukaan stop kran, dengan debit air maksimum sekitar 13 1/s.

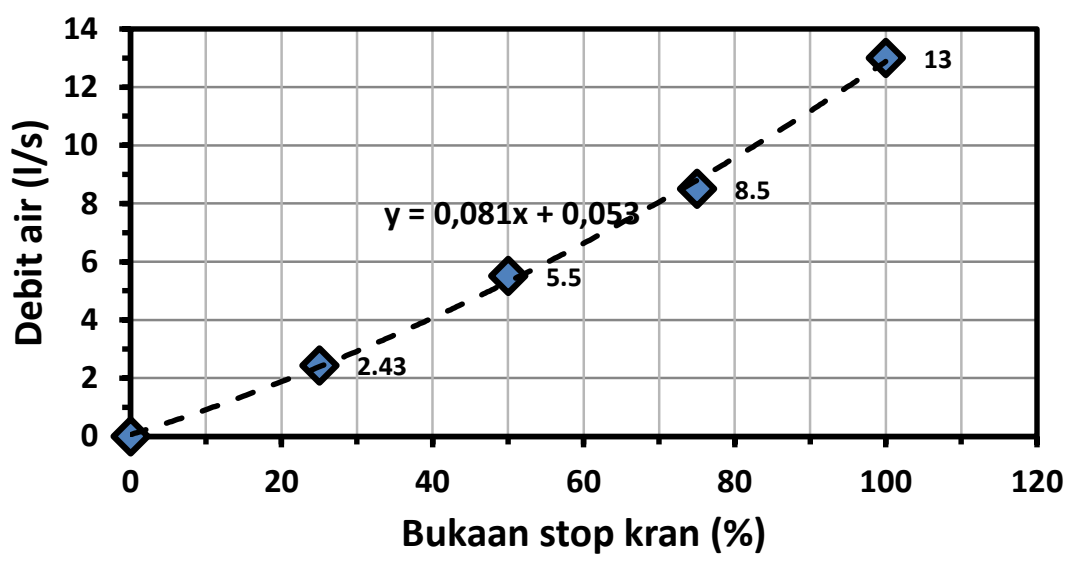

Gambar 5. Hubungan antara debit air (1/s) terhadap bukaan stop kran

Pengaruh debit air (1/s) terhadap putaran turbin dan output tegangan generator DC pada saat tanpa beban memenuhi persamaan: $\mathrm{y}_{1}=-2,038 \mathrm{x}^{2}+55,54 \mathrm{x}-11,83$ dan $\mathrm{y}_{2}=-0,410 \mathrm{x}^{2}+11,12 \mathrm{x}-2,381$, dimana $\mathrm{x}=$ debit air $(1 / s), y_{1}=$ putaran turbin dan $y_{2}=$ output tegangan generator DC, seperti terlihat pada Gambar 6. Putran turbin maksimum dapat mencapai 366 rpm dengan output 72 volt . 


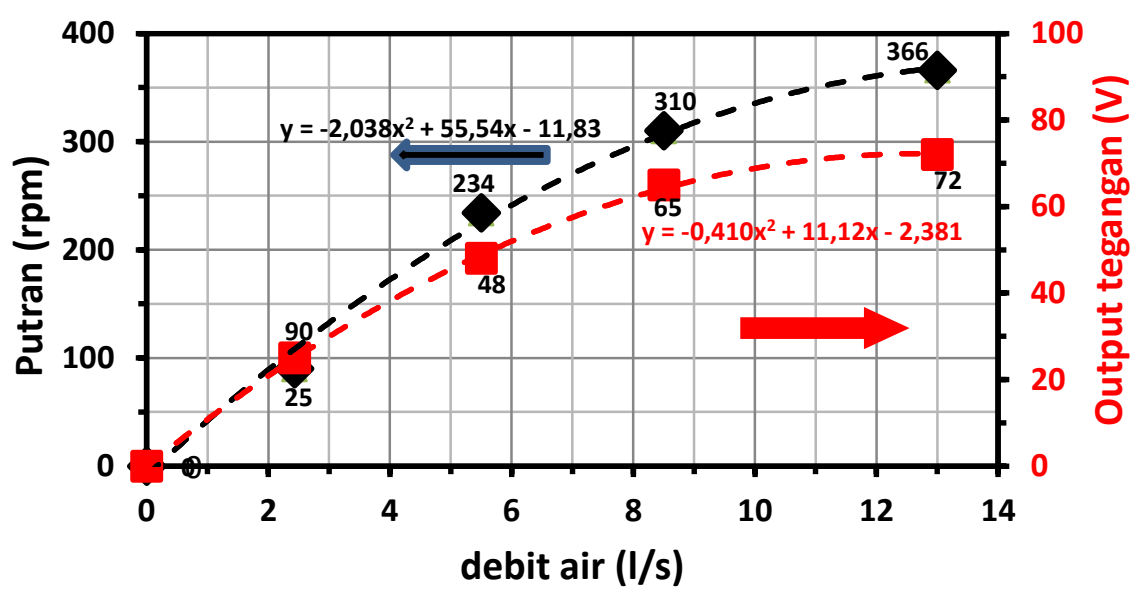

Gambar 6. Korelasi putaran turbin (rpm) dan output tegangan generator DC (V) terhadap debit air (1/s) pada saat tanpa beban.

Pada saat diberi beban masing - masing lampu pijar 5, 18, 25 dan 35 watt putaran turbin generator DC cenderung meningkat, seperti diperlihatkan pada Gambar 7. Semakin tinggi debit air (1/s) dan beban yang bertambah besar, maka output tegangan yang dihasilkan cenderung meningkat. Pada beban lampu pijar 5W memenuhi persamaan polinomial $\mathrm{y}_{\mathrm{a}}=-0,016 \mathrm{x}^{2}+1,598 \mathrm{x}+0,039$, beban lampu pijar $18 \mathrm{~W}$ persamaan menjadi $\mathrm{y}_{\mathrm{b}}$ $=-0,047 \mathrm{x}^{2}+2,520 \mathrm{x}-0,42$, beban lampu pijar 25W adalah $\mathrm{y}_{\mathrm{c}}=-0,086 \mathrm{x}^{2}+3,415 \mathrm{x}-0,59$, dan beban lampu pijar $35 \mathrm{~W}: \mathrm{y}_{\mathrm{d}}=-0,029 \mathrm{x}^{2}+3,474 \mathrm{x}-0,108$, dimana $\mathrm{x}$ adalah kecepatan putar dari turbin. Hal ini tidak berlaku pada saat $\mathrm{x}=0$, karena adanya nilai tegangan yang merupakan faktor koreksi tau merupakan kesalahan. Persamaan ini hanya berlaku dengan syarat batas debit air, $\mathrm{x}=2.42$ sampai $13 \mathrm{l} / \mathrm{s}$.

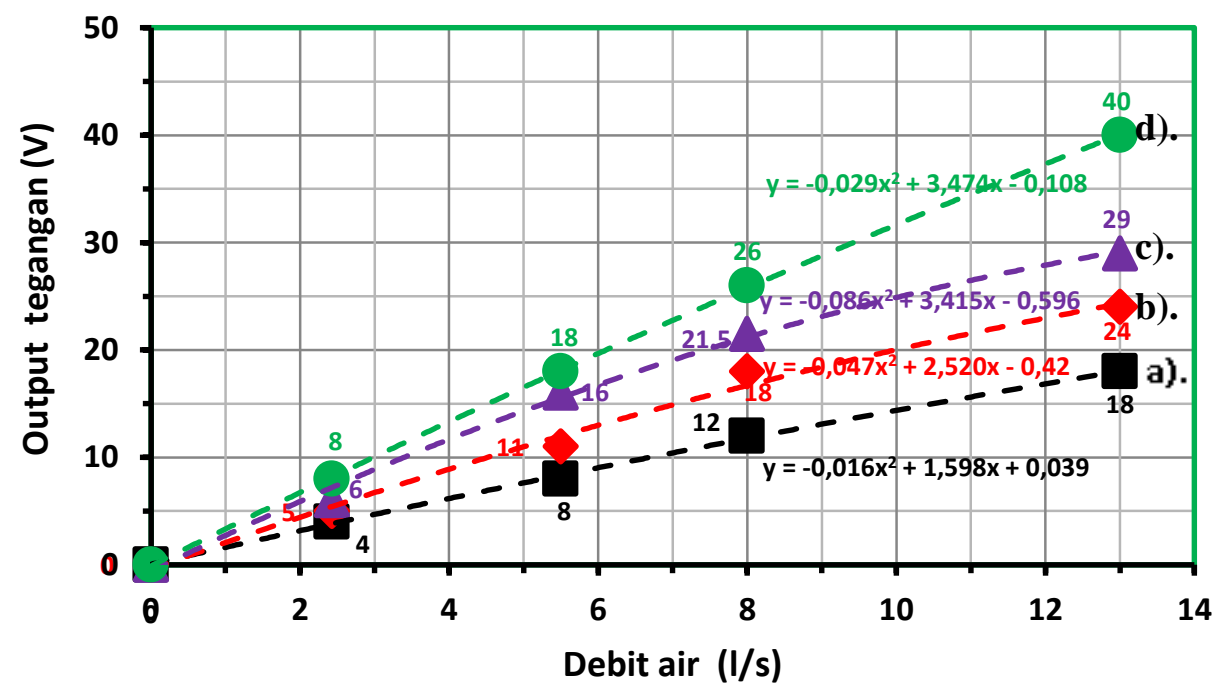

Gambar 7. Hubungan output tegangan Generator DC pada saat beban a). lampu pijar 5 watt, b). 18 lampu pijar watt, c). lampu pijar 25 watt dan d). lampu pijar 35 watt.

Dari hasil pengukuran arus listrik (mA) yang diperoleh semakin besar dengan bertambahnya debit air (1/s) dan beban lampu pijar yang semakin besar, seperti terlihat pada Gambar 8. Hubungan arus listrik Generator DC pada saat beban lampu pijar 5, 18, 25 dan 35 watt. memenuhi persamaan $y_{a}=-0,835 x^{2}+28,71 x-7,149, y_{b}=-$ $5,093 x^{2}+220,9 x-14,46, y_{c}=-8,445 x^{2}+313,0 x-26,53$ dan $y_{d}=-13,09 x^{2}+456,6 x-87,20$, dimana $x=$ kecepatan putar turbin. Nilai ini berlaku dengan syarat batas debit air , $\mathrm{x}=2.42$ sampai $13 \mathrm{l} / \mathrm{s}$. Pada saat debit air dan beban maksimum dapat menghasilkan arus listrik 3,6 A. 


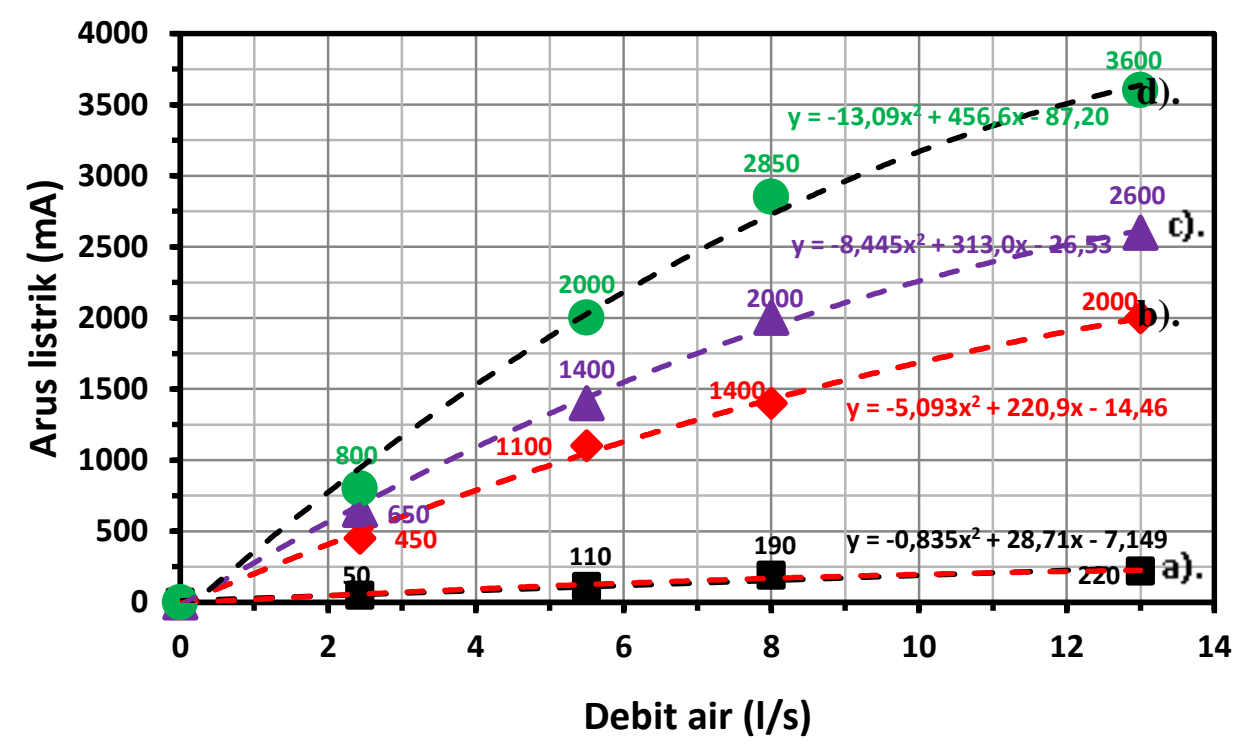

Gambar 8. Hubungan arus listrik Generator DC pada saat beban a). lampu pijar 5 watt, b). 18 lampu pijar watt, c). lampu pijar 25 watt dan d). lampu pijar 35 watt.

Hubungan daya Generator DC (W) pada saat beban a). lampu pijar 5 watt, b). 18 lampu pijar watt, c). Lampu pijar 25 watt dan d). lampu pijar 35 watt diperlihatkan pada Gambar 9. Masing-masing beban lampu pijar 5, 18, 25 dan $35 \mathrm{~W}$ pada debit air $\mathrm{x}=2.42$ sampai $13 \mathrm{l} / \mathrm{s}$ memenuhi persaman sebagai berikut: $\mathrm{Y}_{\mathrm{a}}=0,012 \mathrm{x}^{2}+0,157 \mathrm{x}-$ $0,104, y_{b}=0,162 x^{2}+1,720 x-1,169, y_{c}=0,416 x^{2}+0,162 x+1,256$ dan $y_{d}=0,507 x^{2}+4,862 x-3,356$.

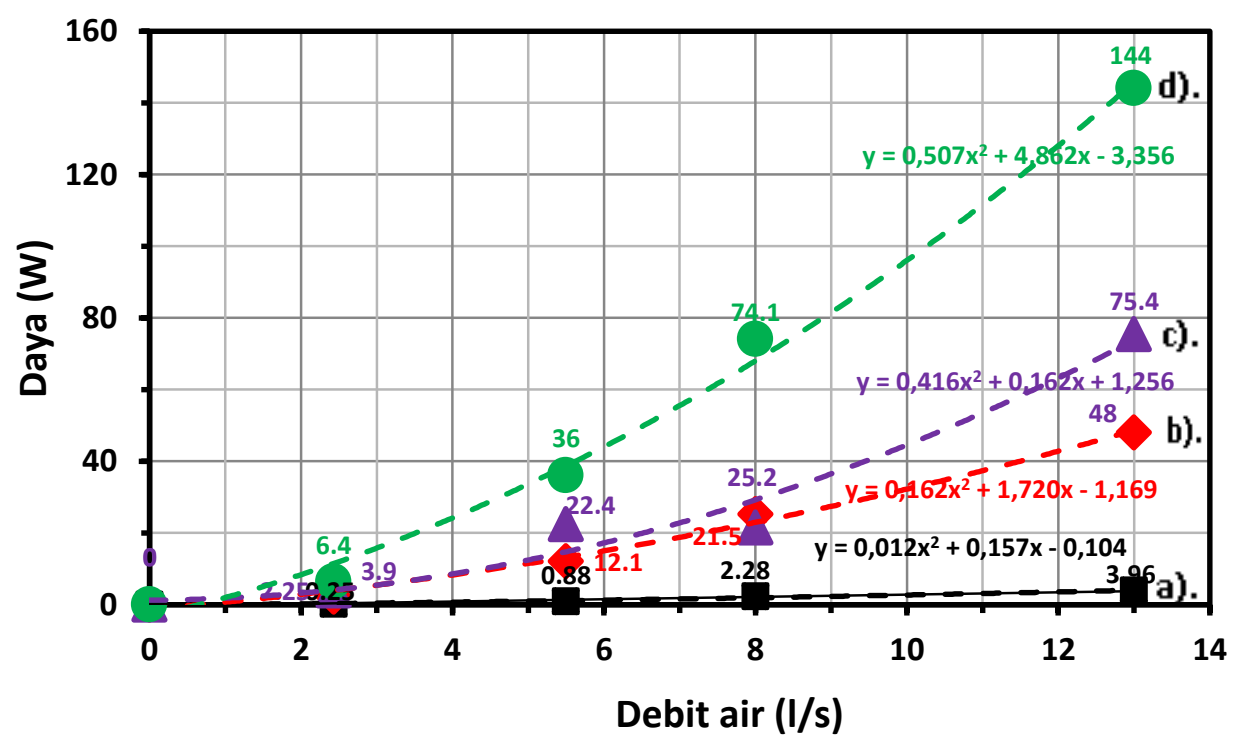

Gambar 9. Hubungan daya Generator DC (W) pada saat beban a). lampu pijar 5 watt, b). 18 lampu pijar watt, c). Lampu pijar 25 watt dan d). lampu pijar 35 watt.

Sedangkan daya input generator DC dan turbin berdasarkan perhitungannya adalah:

$$
P_{T}=g \times \rho \times Q \times H_{n} \quad=9,8 \times 1000 \times 0,013 \times 1,62=206,4 \mathrm{~W} \text {. }
$$

sehingga dapat mencari efisiensi generator DC dan turbin Kaplan dengan persamaan berikut:

$$
\eta_{\text {generator DC dan turbin }}=\frac{\text { Daya output }}{\text { Daya input }} \times 100 \%=\frac{144 \mathrm{~W}}{206,4 \mathrm{~W}} \times 100 \%=69 \% \text {. }
$$




\section{KESIMPULAN}

Rancang bangun Low Head Picohydro telah berhasil dibuat dengan memanfaatkan aliran parit (selokan) dan menggunakan turbin Kaplan. Sistem Low Head Picohydro dengan beda ketinggian $3 \mathrm{~m}$ dan debit air maksimum 13 l/s mampu menghasilkan output tegangan sebesar 40 volt DC dan daya 144 watt. Performa generator DC low head picohydro menghasikan cukup baik dengan efisiensi $69 \%$. Hasil ini belum optimal disebabkan adanya rugirugi aliran di dinding pipa dan inlet penstock. Selain itu bearing dan mainshaft sebaiknya dipasang tidak kena dengan air karena mudah berkarat.

\section{DAFTAR PUSTAKA}

[1] Akbar 2012 Rugi-Rugi Aliran Diperoleh maret 7, 2017, dari https://tajilapak.com/tag/rugi-rugi-aliran/

[2] anonim 2015 Prinsip Kerja Turbin Kaplan. Diperoleh Febuari 3, 2017, dari http://www.satuenergi.com/2015/03/prinsip-kerja-turbin-kaplan.html

[3] antotantan 2016 Answer - How's that Moody Chart Work Again?. Diperoleh maret 9, 2017, dari http://www.learnerds.com/todays-answer/answer-hows-that-moody-chart-work-again

[4] Bere A S, Marsudi S dan Rispiningtati 2010 Studi Pengembangan Pembangkit Listrik Tenaga Air Lodoyo I Pada Bendungan Lodoyo di Deda Gogodeso Kecamatan Kanigoro Kabupaten Jawa Timur. 2.

[5] Coppo A (n.d.). renewablesfirst. Diperoleh Febuari 27, 2016, dari http://www.renewablesfirst.co.uk/hydropower/hydropower-learning-centre/kaplan-turbines/

[6] Benzon D S, Aggidis G A dan Anagnostopoulos J S 2016 Development of the Turgo Impulse turbine: Past and present. Applied Energy, 166,

[7] Dalton S E 2007 Low Head Hydro Techologies and the need for greater uptake and implementation in the UK An Engineer's Perspective. Diperoleh Febuary 6, 2017, dari http://www.britishhydro.org/uploads/11202007120238PM.pdf

[8] Fadli K 2013 Perencanaan turbin air . Diperoleh maret 29, 2017, dari https://khairul_fadli/perencanaanturbin-air

[9] Ferreres X R dan Font A R 2010 Building, Energy And Enviromental Engineering, 26.

[10] Ferreres X R dan Font A R 2010 Instalation of A New Hydropower Plant In Ockelbo (Sweden). 39-46.

[11] Gatte M T dan Kadhim R A 2010 Energy Conservation. In D. A. Ahmed (Ed.), Hydro Power (p. 107). Malaysia : InTech, Chapters published .

[12] Gatte M T dan Kadhim R A 2012 Energy Conservation. In A. Z. Ahmed (Ed.), Hydro Power (p. 97). New Delhi: InTech, Chapters published.

[13] Helmizar 2010 Dinamina Jurnal Ilmiah Teknik Mesin 11

[14] Invitrogen ${ }^{\mathrm{TM}} 2010 p G A P Z A, B$, and $C, p G A P Z \alpha A, B$, and $C$ : Pichia expression vectors for constitutive expression and purification of recombinant proteins. California, USA: Invitrogen Corp.

[15] Jukardi A 2012 Pengertian Bendungan. Diperoleh Febuari 10, 2017, dari http://www.ilmutekniksipil.com/bangunan-air/pengertian-bendungan

[16] Luknanto D 2015 Bangunan Tenaga Air. In Turbin Air (p. 7). Yogyakarta: IUK.staff.ugm. Diperoleh Maret 30, 2017, dari http://luk.staff.ugm.ac.id/bta/TurbinAir.pdf

[17] Mantiq A 2017 Memahami Bilangan Reynold dalam Mekanika Fluida. Diperoleh Juni 31, 2017, dari https://bisakimia.com/2017/02/17/memahami-bilangan-reynold-dalam-mekanika-fluida/

[18] Nuryadin dan Atin 2010 Semayangboy. Diperoleh Januari 26, 2017, dari http://www.semayangboy.com/2010/05/pembangkit-listrik-tenaga-mikrohidro.html

[19] Nuryadin A 2010 Pembangkit Listrik Tenaga Mikrohidro. Diperoleh Januari 27, 2017, dari http://www.semayangboy.com/2010/05/pembangkit-listrik-tenaga-mikrohidro.html

[20] Permatasari R 2008 Bangunan Tenaga Air. In Dasar Teori (p. 23). Semarang: Eorints Undip.

[21] Putra G E 2014 Pemanfaatan beda energi pada bangunan terjun untuk pembangkit listrik tenaga mikrohidro (studi kasus bangunan terjun (BPT2-BPT4) pada saluran irigasi padi pomahan, d.I padi pomahan, desa padi, kecamatan gondang, kabupaten mojokerto. ITS - Undergraduate, 10.

[22] Shantika T dan Ridwan M 2013 Perancangan Prototipe Picohydro Portable 200 watt. Prosiding, 41.

[23] THAPAR P O 2010 modern hydroelectric engineering practice in india electro-mechanical works. in hydraulic turbine classification and selection(p. 54). New Delhi.

[24] Utami P D 2017 Desain, Perancangan, dan Analisa Optimasi Teknologi Gravitational Vortex Hydro Power: Pengaruh Geometri Sudu Turbin. Skripsi Surya University, 1, 35. 